\title{
Structure and Biology of Type VIII Collagen
}

\section{VIII型コラーゲンの構造と生物学}

\author{
M. Luisa Iruela-Arispe, Lawrence E. Chun, and E. Helene Sage \\ Department of Biological Structure, University of Washington, Seattle, WA 98195, USA, FAX: 1-206-543-1524
}

Key Words: cardiogenesis, collagens, Descemet's membrane, endothelial cells, extracellular matrix

\section{Abstract}

Type VIII collagen was initially characterized as a biosynthetic product of bovine aortic endothelial cells in vitro and thus named Endothelial Collagen(EC). The protein has now been identified in avian and mammalian species as a product secreted by cultured corneal endothelial cells, keratinocytes, fibroblasts, astrocytoma and other tumor cells, and endothelial cells derived from several classes of blood vessels. In vivo, the distribution of type VIII collagen is restricted to specialized extracellular matrices such as meninges, periosteum, perichondrium, and Descemet's membrane of the comea. It is also present in the subendothelium of large and small blood vessels and has been localized in capillary-like structures formed by sprouting cultures of endothelial cells. Data from protein and nucleotide sequencing have identified two distinct chains, termed $\alpha 1$ (VIII) and $\alpha 2$ (VIII); however, the assembly of these chains in the extracellular space is still poorly understood. Protein extracts from Descemet's membrane indicate that, in this tissue, type VIII collagen is a heterotrimer. Our understanding of the biological role of type VIII collagen is rather limited. Although type VIII collagen seems to perform a structural role in the Descemet's membrane, its temporally and spatially restricted expression during development suggests an involvement in tissue remodeling and differentiation.
要旨

VIII型コラーゲンは、ウシ大動脈内皮細胞の培養系におけ る生合成産物として最初に報告されたので、従来は内皮細胞コ ラーゲン(EC)と呼ばれていた。このタンパク質は現在、トリお よび哺乳類のケラチノサイト、線維芽細胞、星状細胞腫や他の 腫瘍細胞、さらに様々な大きさの血管に由来する内皮細胞など によって分泌されることが知られている。生体内ではVIII型コ ラーゲンの分布は限られており、例えば嗵膜、骨膜、軟骨膜、 角膜のデスメ膜などの細胞外マトリックスに存在する。また大 小血管の内皮下層や内皮細胞の発芽培養系で形成される毛細血 管梯構造にも存在する。タンパク質のアミノ酸配列と核酸程基

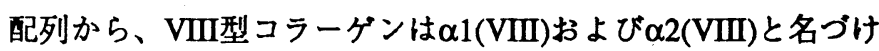
られた2本の異なる $\alpha$ 鎖から構成されていることが明らかにされ たが、細胞外の場所ではこれらの $\alpha$ 鎖がどのような会合体を 作っているのかまだよくわかっていない。しかしデスメ膜から タンパク質を抽出したところ、VIII型コラーゲンはこの組織に おいてへテロ3本鎖構造をとっていることが示された。一方VIII 型コラーゲンの生物学的機能に関する我々の知識はまだまだ不 足している。VIII型コラーゲンはデスメ膜の特殊な六角格子構 造の形成に関与していると考えられているが、発生分化の過程 では本コラーゲンの発現は一定の期間、特定の場所に限られて おり、このことから組織再構築や分化にも関与していると思わ れる。

\section{A. Introduction}

Collagens are members of a large family of proteins that share at least three common characteristics: i) an extended sequence or sequences containing the repeating tripeptide Gly-X$\mathrm{Y}$, which allows collagen $\alpha$ chains to form triple-helical molecules; ii) organization of homotypic or heterotypic supramolecular aggregates, and iii) an extracellular location(1). For many years, collagens were believed to play primarily, if not exclusively, a structural role. However, it has been recently appreciated that collagens can also influence basic cellular properties that include cell shape, proliferation, and differentiation. Although the molecular mechanisms by which these macromolecules initiate cellular responses are not understood, there is evidence that signal transduction through cell surface receptors such as integrins might be involved (reviewed in ref. 2).

Over the last decade, considerable progress has been
A. はじめに

コラーゲンは多数のメンバーからなるタンパク質の一大 ファミリーを形成しており、少なくとも3つの共通する特徽を 持っている。i)Gly-X-Yというトリペブチドの繰り返し構造から 成る一連の長いアミノ酸配列、または綝り返し棈造が分断され た配列を持ち、この繰り返し構造によりコラーゲンの风鎖は3本 鎖ヘリックス構造を形成することができる、ii)単一ないしは複 数のタイブから構成される超分子集合体を形成する、iii)細胞外 に存在するーという特徴である(1)。長い間コラーゲンは、主と して組穖の構造を支える役割を果たしていると信じられてき た。しかし近年、コラーゲンは基本的な細胞の性質、すなわち 細胞の形態、增殖、分化に影響を及はすことが諗識されるよう になってきた。これら高分子物質が細胞側の応答を開始させる 分子機構については明らかではないが、インテグリンのような 細胞表面の受容体を介する情報伝達機構が関与していることが 証明されている(文献2に概説)。 
made in understanding how collagen gene expression is regulated (for a review, see ref. 3). In addition, the molecular cloning and sequencing of the collagen genes has provided new information on the structure of this large family of proteins. Consequently, the collagen family has been categorized into five basic groups: i) fibrillar collagens(types I, II, III, V, and $\mathrm{XI}$ ); ii) collagens that do not form typical banded fibrils(types VI, VII, and XIII); iii) fibril-associated collagens with interrupted triple-helices, or FACIT collagens(types IX, XII, and XIV); iv) basement membrane collagens(type IV), and v) short-chain collagens(type $\mathrm{X}$ )(4). Our present knowledge of the structure of the type VIII collagen gene identifies it as a short-chain collagen that appears to be closely related to type X.

In this review we provide an overview of the research that has been conducted on type VIII collagen genes and proteins and discuss some of the basic observations that have been made regarding its biological function.

\section{B. Structure of Type VIII Collagen}

The primary structure of type VIII collagen has recently been elucidated by the cloning and sequence analysis of two new collagen genes, designated COL8A1 and COL8A2. The identity of these genes with collagenous peptides isolated from Descemet's membrane has led to their description as the $\alpha 1$ and $\alpha 2$ chains of type VIII collagen, respectively. At present, sequence data have been reported for the rabbit $\alpha 1$ (VIII) gene(5), human $\alpha 1$ (VIII) gene(6), and the mouse and human $\alpha 2$ (VIII) genes(7). The molecular data corroborate earlier protein stud-
ここ10年余りの間に、どのようにコラーゲン遺伝子の発現 が調節されているかを理解する上で、めざましい進展があっ た(文献3に概説)。さらに、コラーゲン遺伝子の分子クローニン グや塩基配列の決定により、この一大ファミリーのタンパク質 の構造に関して新しい情報が得られた。その結果、コラーゲン ファミリーは5つの基本的グループに分類されている。すなわ ち、i)線維形成型コラーゲン*1(I、II、III、V、XI型)、ii)典型的 な縞模様を示す線維を形成しないコラーゲン(VI、VII、XIII 型)、iii)中断した三本鎖ヘリックス構造を持ち、線維型に会合し ているコラーゲン、これはFACIT*2コラーゲンとも呼ばれる (IX、XII、XIV型)、iv)基底膜コラーゲン(IV型)、v)短鎖コラー ゲン(X型)、である(4)。VIII型コラーゲン遺伝子の構造に関する 情報によれば、本コラーゲンは短鎖コラーゲンであり、X型と 非常に近縁な関係にあると考えられている。この総説では、 VIII型コラーゲンの遗伝子及びタンパクに関する研究成果を概 説し、生物学的機能に関する基本的な知見について解説する。

\section{B. VIII型コラーゲンの構造}

近年、VIII型コラーゲンの一次構造が、COL8A1、 COL8A2と称される2つの新しいコラーゲン遺伝子のクローニン グと塩基配列決定により明らかにされた。デスメ膜から単離さ れたコラーゲンのペプチドと、これらの遺伝子から推定される アミノ酸配列が一致したことから、それぞれVIII型コラーゲン $の \alpha 1 、 \alpha 2$ 鎖と記述された。現在ウサギ $\alpha 1(\mathrm{VIII})$ 遺伝子(5)、ヒ卜

"1これらのコラーゲンが形成する線維は、電子顕微鏡下でコ ラーゲンに特有な一定周期の横縞を示す

${ }^{* 2}$ Fibril Associated Collagen with Interrupted Triple helces

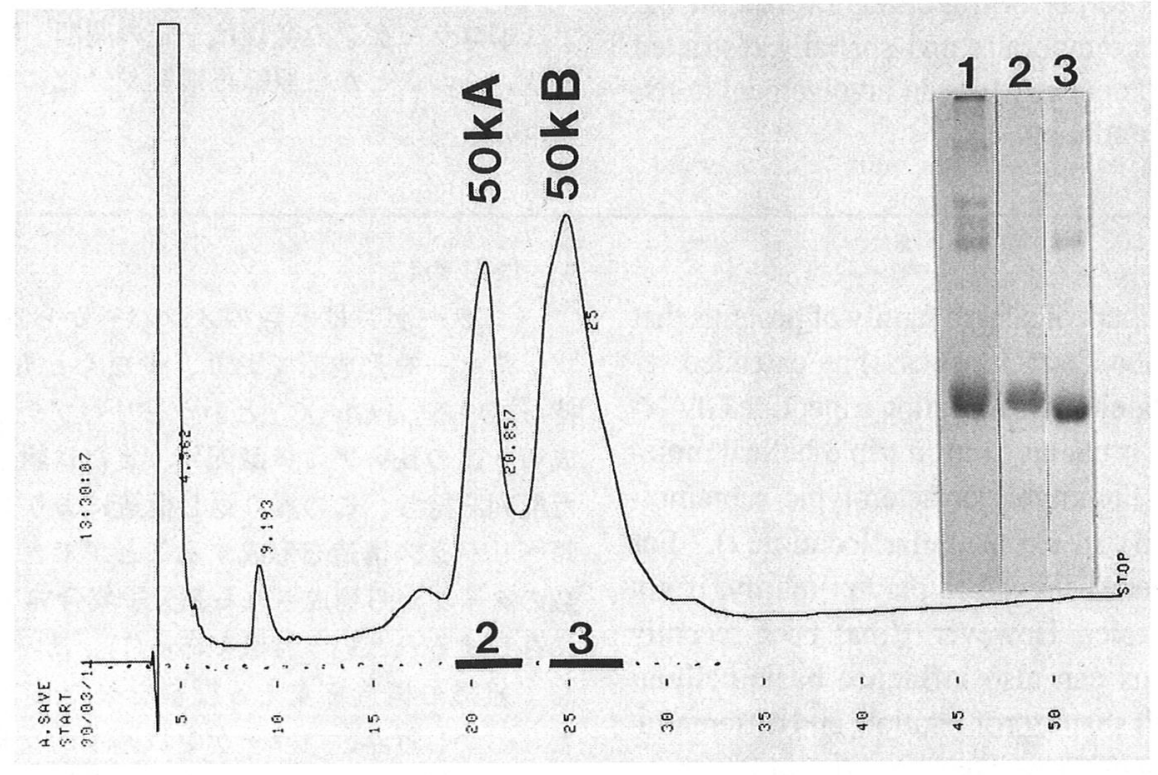

Fig. 1. Purification of $\alpha 1$ (VIII)(50K-B) and $\alpha 2$ (VIII)(50K-A) from extracts of Descemet's membrane by high performance liquid chromatography(HPLC). Type VIII collagen, isolated from bovine Descemet's membrane by pepsin digestion and differential salt fractionation(lane 1), was resolved into two polypeptide chains by reverse-phase HPLC. $200 \mu \mathrm{g}$ of protein was solubilized in $1 \%$ trifluoroacetic acid and chromatographed on a Vydac C18 column with a linear gradient of $15-40 \%$ acetonitrile : water( $(60: 40 \mathrm{v} / \mathrm{v})$ in $0.1 \%$ trifluoroacetic acid over $60 \mathrm{~min}$.

Insert: Sodium dodecyl sulfate-polyacrylamide gel electrophoresis of 50K-A(lane 2) and 50K-B(lane 3) purified by HPLC. 
COL8A1 gene

$\alpha_{1}$ (VIII) chain

B.

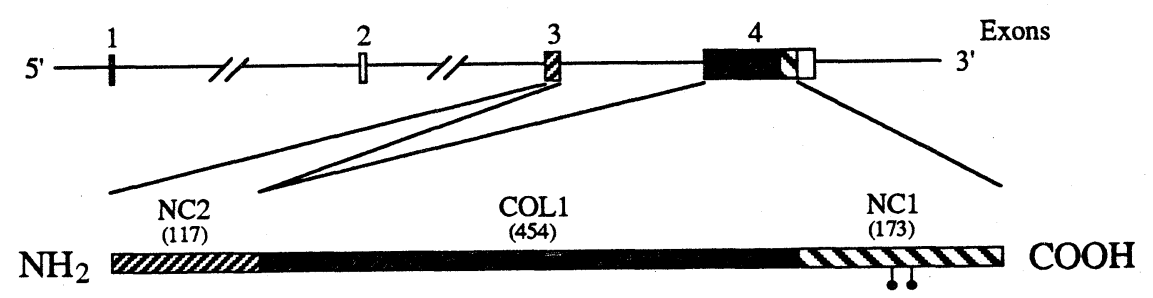

ग!

$\alpha_{2}$ (VIII) chain $\quad \mathrm{NH}_{2}$

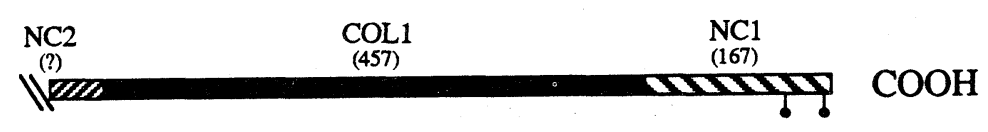

Fig. 2. Diagram of the COL8A1 gene and the $\alpha 1$ (VIII) and $\alpha 2$ (VIII) polypeptide chains of type VIII collagen.

A. Schematic representation of the COL8A1 gene and its translation product, the $\alpha$ 1(VIII) chain. In COL8A1, exons are represented in boxes and are numbered from the $5^{\prime}$ end of the gene. Exons 1,2, and three nucleotides of exon 3 contribute to the 5' untranslated region of $\alpha 1$ (VIII) mRNA. The rest of exon 3 encodes the majority of the amino-terminus(NC2). Exon 4 encodes a small part of the NC2 domain(7 $2 / 3$ codons), the entire triple-helical domain(COL1), the carboxy-terminus( $\mathrm{NC} 1)$, and the 3 ' untranslated region. The numbers of amino acids in $\mathrm{NC} 2, \mathrm{COL} 1$, and $\mathrm{NC} 1$ are indicated in parentheses.

B. Diagram of the $\alpha 2$ (VIII) chain. The exact number of nucleotides of the NC2 domain is not known. The triple-helical domain(COL1) contains 457 amino acids and the carboxy- terminus( $\mathrm{NC1}$ ) contains 173 amino acids.

Cysteines are indicated ( ).

ies that predicted the existence of two structurally distinct type VIII collagen polypeptides(50K-A and 50K-B) in bovine corneal Descemet's membrane(8). Additional type VIII collagen peptides isolated from rabbit Descemet's membrane $(9,10)$ match the predicted DNA sequences and indicate that the structure of type VIII collagen is conserved among several mammalian species. Fig.1 identifies 50K-A and 50K-B after extraction from bovine Descemet's membrane and further purification by high performance liquid chromatography.

From an analysis of the nucleotide sequence, type VIII collagen contains a central triple-helical(COL1) domain of 454 amino acids[rabbit $\alpha 1$ (VIII)] or 457 amino acids [human $\alpha 2$ (VIII)], that is flanked by short non-collagenous extensions. The molecular weight of an intact chain is estimated to be 60,000 . Fig. 2 shows the basic structure of the $\alpha 1$ and $\alpha 2$ chains of type VIII collagen. The triple-helical domain, composed of Gly-X-Y repeats, is characterized by the presence of eight imperfections located at the same relative position within each $\alpha$ chain. This pattern of helix interruption distinguishes type VIII collagen from the other short collagenous sequences found in types IV, VI, IX, and XII collagens(11). Curiously, type X collagen also contains a similar pattern of helix imperfections(9). Furthermore, the sequence identity between the rabbit $\alpha 1(\mathrm{VIII})$ and the chicken $\alpha 1(\mathrm{X})$ chains in the collagenous (COL1) domain is $57 \%$ at the nucleotide level; even greater sequence conservation is seen in the carboxy-terminal portion of the non-collagenous domain $\mathrm{NC1}(9)$. Moreover, the primary structures of the $\alpha 1$ (VIII), $\alpha 2$ (VIII), and $\alpha 1$ (X) chains are $\alpha 1(\mathrm{VIII})$ 遺伝子(6)、マウスおよびヒト $\alpha 2(\mathrm{VIII})$ 遺伝子(7)の塩基 配列データが報告されている。これらの分子データは、ウシ角 膜デスメ膜に二種の構造的に異なるVIII型コラーゲンペプチド (50K-A および50K-B)が存在することを予想したタンパク質側の 研究結果を裹付けるものである(8)。さらに新たなVIII型コラー

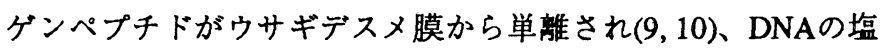
基配列から予想されるアミノ酸配列と一致したことより、VIII 型コラーゲンの構造は数種の哺乳類間で保存されていることが 指摘された。図1はウシデスメ膜よりタンパクを抽出後、高速液 体クロマトグラフィーにより精製した50K-A と50K-B断片を示 している。

核酸塩基配列を分析した結果、VIII型コラーゲンはウサギ

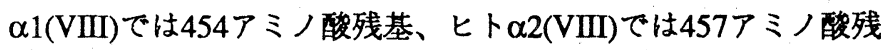
基からなる中央の三本鎖ヘリックス領域(COL1)を含んでおり、 その両端から短い非コラーゲン領域が伸びている構造をしてい ることがわかった。完全な $\alpha$ 鎖の分子量は約6万と推定されてい る。図2には、VIII型コラーゲンの $\alpha 1$ および $\alpha 2$ 鎖の基本的な構 造を示した。Gly-X-Yの綝り返し構造から構成される三本鎖へ リックス領域にはトリブレットが不完全な部分が8ケ所存在し、 各鎖においてその相対的な位置は一致している。このへリッ クス構造中断のパターンはVIII型コラーゲンと他の短いコラー ゲン配列を持つIV、VI、IXおよびXII型コラーゲンとでは全く 異なっている(11)。しかし奇妙なことにX型コラーゲンはVIII型 コラーゲンと同様なヘリックス構造中断のパターンを示す(9)。 さらに、ウサギ $\alpha 1(\mathrm{VIII})$ とトリ $\alpha 1(\mathrm{X})$ 鎖のコラーゲン領域(COL1) における核酸レベルの配列相同性は57\%であり、カルボキシ末 端側の非コラーゲン領域NC1では、さらに両鎖間で配列が保存 
highly similar. These features have led Yamaguchi and coworkers $(5,9)$ to propose a common evolutionary origin for the three chains.

Diversity of structure is more apparent in the NC2 domain of these collagens. This region in the $\alpha 1$ (VIII) chain, which shows little sequence homology with a comparable region of $\alpha 1(\mathrm{X})$, is composed mainly of basic amino acids, with an estimated pI of 10.6 for both the rabbit and human $\alpha 1$ (VIII) chains $(6,9)$. Differences in the NC2 domain may thus direct the tissue-specific organization of type $\mathrm{X}$ collagen in hypertrophic cartilage, and that of type VIII collagen in Descemet's membrane. In both collagens, the conserved regions of the COL1 and $\mathrm{NC1}$ domains might participate in intramolecular interactions such as triple-helix formation and multimeric assembly, whereas interactions between the NC2 domain and polyanionic molecules such as proteoglycans or glycosaminoglycans might participate in the organization of specific extracellular matrices.

Another unique feature of the type VIII collagen helix is the unusually high content of hydroxyproline (Hyp) residues. For example, $\alpha 2$ (VIII) contains 167 residues of Hyp per 1,000 amino acids(10). In comparison, type I collagen typically contains 85 Hyp per 1,000 amino acids(12). This characteristic could account for the melting temperature(Tm) of type VIII collagen $\left(41^{\circ} \mathrm{C}\right)$, which is higher than those of the fibrillar collagens $\left(\mathrm{Tm}=35-37^{\circ} \mathrm{C}\right)(13)$. It is interesting that type $\mathrm{X}$ collagen also has a high content of Hyp and a high thermal stability $\left(\mathrm{Tm}=47^{\circ} \mathrm{C}\right)(14)$.

Relatively little is known about the organization of type VIII collagen within extracellular matrices. Several structural models have been proposed that were based on the characterization of type VIII collagen purified as a soluble protein from cell culture media or isolated from the insoluble components of Descemet's membrane. These models include a cassette model(8), the interrupted helix model(15), and a "conventional" model(16) with the chain composition[ $\alpha 1$ (VIII) $]_{2}$ $\alpha 2$ (VIII)(10). Recent evidence from studies of gene structure supports the conventional model that was based on a homotrimeric or heterotrimeric arrangement of $\mathrm{Mr} 60,000$ chains in a typical collagen triple helix. Higher molecular weight forms of type VIII collagen[e.g., EC1, 2, and 3 (reviewed in 17); 300K, $200 \mathrm{~K}$, and $100 \mathrm{~K}(18)$, and $\mathrm{Mr} 185,000$ disulfide-bonded complexes(19)], cannot presently be reconciled with the conventional model. The identity of these high molecular weight forms and their structural relationship to $50 \mathrm{~K}-\mathrm{A}$ and $50 \mathrm{~K}-\mathrm{B}$ remain to be clarified.

Another enigma surrounding the type VIII collagen protein is the question of its trimeric structure. The identification of two distinct collagen genes is suggestive of several distinct isoforms that include homotrimers of $\alpha 1$ (VIII), homotrimers of $\alpha 2$ (VIII), and/or heterotrimers of $\alpha 1$ (VIII) and $\alpha 2$ (VIII).
されている(9)。 $\alpha 1(\mathrm{VIII}) 、 \alpha 2(\mathrm{VIII}) 、 \alpha 1(\mathrm{X})$ 鎖の一次構造は非常 によく似ており、これらの特徴からYamaguchiと共同研究者 $(5$, 9)はこれら3本の $\alpha$ 鎖は共通の柤先から進化したのではないかと 考えている。

ところが、これらのコラーゲンのNC2領域には明らかな構 造の多梯性が認められる。 $\alpha 1(\mathrm{VIII})$ 鎖のNC2領域は、 $\alpha 1(\mathrm{X})$ との 類似性がなく、ウサギおよびヒト $\alpha 1$ (VIII)鎖両鎖とも塩基性了 ミノ酸で構成され、等電点は 10.6 と算定されている $(6,9)$ 。 NC2 領域における両鎖の違いは、X型コラーゲンが肥大軟骨の、ま たVIII型コラーゲンがデスメ膜のそれぞれ組織特異的な構造を 形成するのに関係しているのかもしれない。両コラーゲンで保 存されている領域、COL1とNC1領域は、三本鎖ヘリックス構造 の形成や、集合体の構築などの分子間相互作用に関与し、一 方、NC2領域はプロテオグリカンやグリコサミノグリカンなど の多価除イオン性分子と相互作用して、組織特異的な細胞外マ トリックスの構築に関与しているのであろう。

VIII型コラーゲンのもう一つの特徵は、ハイドロキシブロ

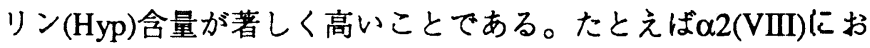
いては、1,000残基のアミノ酸中、Hypが167残基を占める(10)。 これに対して、I型コラーゲンにおけるHyp含量は、 1,000 残基の アミノ酸中、85残基である(12)。この特異的な性質が型などの 線維型コラーゲンの変性温度 $\left(\mathrm{Tm}=35-37^{\circ} \mathrm{C}\right)$ より VIII型コラーゲ ンの変性温度 $\left(\mathrm{Tm}=41^{\circ} \mathrm{C}\right)$ が高い原因であろう(13)。X型コラーゲ ンもまたHyp含量が高く、高い変性温度 $\left(\mathrm{Tm}=47^{\circ} \mathrm{C}\right)$ を示すのも 興味深い(14)。

VIII型コラーゲンの細胞外マトリックスにおける形態につ いては、まだよく分かっていない。何種類かの構造モデルが提 案されているが、それらはすべて細胞培養液から得られる、可 溶性タンパク質として精製されたVIII型コラーゲンかデスメ膜 の不溶性成分から単離されたVIII型コラーゲンの性質に基づい ている。これらのモデルは、カセットモデル(8)、中断したへ リックス構造モデル(15)、そして $[\alpha 1(\mathrm{VIII})]_{2} \alpha 2(\mathrm{VIII})$ の鎖構成か ら成る典型的なコラーゲンモデル(10)である。近年、遗伝子構 造の研究から、上述のモデルのうち典型的なコラーゲンモデ ル、すなわち分子量 60,000 の同一種の $\alpha$ 鎖から形成されるホモ三 本鎖または、異種の $\alpha$ 鎖から形成されるへテロ三本鎖よりなる 典型的なコラーゲン三本鎖ヘリックスのモデルが正しいことが 証明された。

高分子量のVIII型コラーゲン[例えばEC1，2，3(文献17に概 説];分子量 $300 \mathrm{~K} 、 200 \mathrm{~K} 、 100 \mathrm{~K}(18)$ 、さらに分子量185,000のジス ルフィド結合した複合体(19)]は、現在のところ典型的なコラー ゲンモデルとは一致しない。これら高分子量の形態が存在する こと、それらの構造が50K-Aや50K-B とどのような関係にある のかは不明である。

VIII型コラーゲンタンパクに関するもう一つの謎は、その 三本鎖構成が明らかでないことである。二種のコラーゲン遺伝 子が同定されたことから、数種のイソ型、すなわち $\alpha 1(\mathrm{VIII})$ の ホモ三本鎖ないしは $\alpha 1(\mathrm{VIII})$ と $\alpha 2(\mathrm{VIII})$ から成るへテロ三本鎖が 存在する可能性がある。これらの組み合わせは、二本の $\alpha(\mathrm{VIII})$ 
These combinations are based on the existence of only two $\alpha$ (VIII) polypeptide chains. It is conceivable that type VIII collagen might be similar in one respect to type IV collagen, for which five chains and several molecular permutations have been described in different tissues (for a review, see ref. 4). Alternatively, a type VIII collagen heterotrimer might be composed of $\alpha$ chains of different molecular sizes(19), a configuration that characterizes the structure of type VI collagen(4). The collagen family continues to provide us with a wide variety of examples in which changes in secondary structure can result in rather diversified functions.

\section{Type VIII Collagen Genes}

The isolation of an $\alpha 1$ (VIII) collagen cDNA from rabbit corneal endothelial cells by Yamaguchi et al.(9) has led to the cloning and sequencing of the rabbit COL8A1 gene(5), human COL8A1 gene(6), and human and mouse COL8A2 genes(7). The rabbit COL8A1 gene contains four exons of irregular size. The first two exons(69 and $120 \mathrm{bp}$, respectively) code for the $5^{\prime}$ untranslated region; exon 3(331 bp) and exon 4(2,278 bp) encode the translated portion. The inclusion of the entire triplehelical domain within a single exon (exon 4 ) contributes to the unusual structure of this gene(Fig. 2A). With the exception of type $\mathrm{X}$ collagen and collagens of some invertebrate species, all known collagenous domains are encoded by multiple exons (11). Partial characterization of human COL8A1 and human

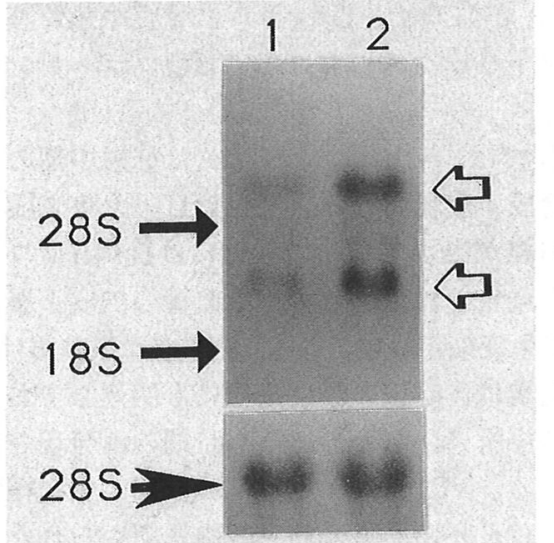

Fig. 3. Detection of $\alpha 1$ (VIII) collagen mRNA in rabbit tissues. Total RNA was purified from neonatal rabbit cornea(lane 1) and neonatal rabbit retina, choroid, and sclera(lane 2). $10 \mu \mathrm{g}$ of total RNA from these preparations was denatured and resolved on a $1.2 \%$ agarose gel. After electrophoresis, the RNA was transferred onto nitrocellulose and the resulting Northern blot was hybridized with an $\alpha 1$ (VIII) collagen cDNA(2.2kb)(a gift from Dr. Y. Ninomiya, Okayama University, Okayama, Japan). The open arrows indicate two type VIII collagen mRNAs of $2.5 \mathrm{~kb}$ and $3.8 \mathrm{~kb}$. Positions of migration of the $28 \mathrm{~S}$ and $18 \mathrm{~S}$ ribosomal subunits are shown.

From scanning densitometry and subsequent normalization (to 28S rRNA) for equal amounts of blotted RNA, mRNA in lane 2 was increased 2.8-fold over that seen in lane 1. Immunocytochemical studies have indicated that these differences might reflect the large number of vessels identified in the choroid that express high levels of type VIII collagen at birth.
ポリペプチド鎖しか存在しないことに基づいている。IV型コ ラーゲンには、五種の $\alpha$ 鎖が存在し、種々の組織での分子型、 すなわち異なる $\alpha$ 鎖の組み合わせから成る分子が報告されてい る(文献4を参照)。VIII型コラーゲンもこの点でIV型コラーゲン と似ている可能性がある。さらに、VIII型コラーゲンのへテロ 三本鎖は、分子量の異なる $\alpha$ 鎖で構成されている可能性もあり (19)、このような形態はVI型コラーゲンの特徴である(4)。コ ラーゲンファミリーは、二次構造の多様性によって多彩な機能 が生みだされるという様々な例を我々に示してくれる。

\section{VIII型コラーゲン遺伝子}

$\alpha 1(\mathrm{VIII})$ コラーゲンcDNAはYamaguchiら(9)によってウサギ 角膜内皮細胞から単離され、それによりウサギCOL8A1遺伝子 (5)、ヒトCOL8A1遺伝子(6)、更にヒトおよびマウスCOL8A2遺 伝子(7)が次々とクローニングされ、塩基配列が決められた。ウ サギCOL8A1遺伝子は大きさの異なる4つのエクソンを含んでい

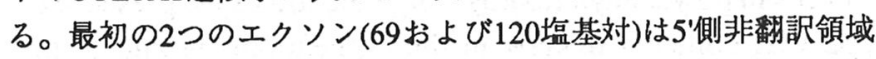
をコードしており、3番目のエクンン(331塩基対)と4番目のエク ソン(2278塩基対)が翻訳領域をコードしている。三本鎖ヘリッ クス領域全体が1つのエクンン(第4エクソン)に含まれているこ とは、コラーゲンとしては異例な遺伝子構造を持つことを示し ている(図2A)。X型コラーゲンやある種の無脊椎動物のコラー ゲンを除いて、既知のすべてのコラーゲン領域は多数のエクソ ンに分断されてコードされている(11)。ヒトCOL8A1、ヒトおよ びマウスCOL8A2遺伝子の特徴を検討した結果、このユニーク な遺伝子構造は数種の哺乳類に共通して認められた。in situハイ ブリダイゼーション法により、ヒトCOL8A2遺伝子は第1染色体 に(7)、ヒトCOL8A1遺伝子は第3染色体に(6)存在することがわ かった。

現時点ではプロモーター配列、ならびにエンハンサー、リ プレッサーモチーフに関する研究報告はなされていない。ウサ ギ角膜内皮細胞に $\alpha 1$ (VIII)および $\alpha 2(\mathrm{VIII}) \mathrm{mRNA}$ の存在が確認さ れ(7,9)、各々のポリペプチドがウシデスメ膜の抽出物中に存在 することから(8)、VIII型コラーゲンの両 $\alpha$ 鎖とも角膜に発現さ れていることが指摘された。ノーザン分析からウサギ $\alpha 1$ (VIII) 遺伝子は2,500から 3,800 塩基対長の3種のmRNAに転写発現され

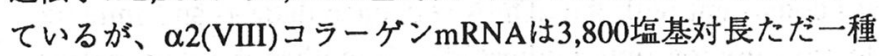

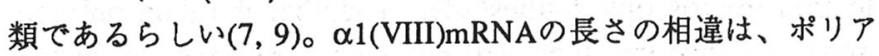
デニル化の位置の違いが原因であると考えられている(5)。図3 はVIII型コラーゲンmRNAがウサギ新生仔の角膜(レーン1)、強 膜、脈絡膜、網膜(レーン2)に存在することを示している。

\section{VII型コラーゲンの分布と分子形態:組織形態形成にお ける役割? \\ 成体の器官のうちで最もVIII型コラーゲン含量が高いのは デスメ膜である $(20,21)$ 。デスメ膜は厚い基底膜様の構造を持 ち、角膜の実質と内皮の中間に位置している。デスメ膜のVIII 型コラーゲンは大部分4 Mグアニジン塩酸に不溶性で(13)、ペプ シンにより切断される結合を介してマトリックスと会合してい}


and mouse COL8A2 indicates that the unique structure of these genes has been conserved in several mammalian species. In situ hybridization studies have shown that the human COL8A2 gene is located on chromosome 1(7), whereas the human COL8A1 gene is located on chromosome 3(6). At this point no studies have been published that identify promoter sequences and/or enhancer/repressor motifs.

Identification of $\alpha 1$ (VIII) and $\alpha 2$ (VIII) mRNA in rabbit corneal endothelial cells $(7,9)$ and the presence of each polypeptide in extracts of bovine Descemet's membrane(8) indicate that both chains of type VIII collagen are expressed in the cornea. Northern analysis has shown that the rabbit $\alpha 1$ (VIII) gene is expressed as 3 distinct mRNAs that range in size from 2,500 to 3,800 nucleotides, whereas $\alpha 2$ (VIII) collagen mRNA appears to be a single species of 3,800 nucleotides $(7,9)$. Variations in size of $\alpha 1$ (VIII) mRNA are believed to be due to differences in polyadenylation(5). Fig. 3 illustrates the presence of type VIII collagen mRNA in the cornea(lane 1) and in the sclera, choroid, and retina(lane 2 ) of neonatal rabbits.

\section{Distribution and Molecular Organization of Type VIII Collagen: A Role in Tissue Morphogenesis?}

In adult organisms, the highest concentration of type VIII collagen can be found in Descemet's membrane $(20,21)$, a thick basement membrane-like structure situated between the stroma and the endothelium of the cornea. Type VIII collagen from Descemet's membrane is largely insoluble in $4 \mathrm{M}$ guanidinium hydrochloride(13) and remains associated with the matrix through pepsin-sensitive linkages. Matrix interactions involving desmosine crosslinks(22) or disulfide bridges(17) do not appear to be involved. Electron microscopy revealed that the Descemet's membrane is formed by an hexagonal latticelike structure with basic units of $160 \mathrm{~nm}(23)$. Rotary shadowing images of type VIII collagen isolated from either cell culture(5) or pepsin digests of tissue(13) revealed a rod-like molecule of approximately $132 \mathrm{~nm}$ with knob-like extensions at each end, with an overall length of $160 \mathrm{~nm}(9)$. This structure was consistent with the cDNA sequence data(9) and immunoelectron microscopy studies(24). Together the data provide strong evidence that type VIII collagen is responsible for the hexagonal lattice structure observed in Descemet's membrane(24). Although it was less abundant, type VIII collagen has also been described in other areas of the eye such as Bruch's membrane, the cribiform plates of the optic nerve, the walls of Schlemm's canal, and the choroid stroma(25).

Type VIII collagen has also been identified in other specialized extracellular matrices that include perichondrium, periosteum, meninges, and sclera $(26,27)$. In addition, Kittelberger and co-workers(28) have described type VIII collagen in the connective tissue sheath that surrounds hair follicles. This sheath is rich in oxytalan fibers(microfibrils)(29), and
る。デスモシン架橋結合(22)やジスフィルド架橋(17)などによる マトリックス相互作用は、関与していないと思われる。デスメ 膜を電子顥微鏡下で観察すると、1つの格子の単位が $160 \mathrm{~nm}$ の六 角形の格子構造が見られる(23)。細胞培養(5)ないしは組織をペ プシン消化して(13)得られたVIII型コラーゲンのロータリーシャ ドウイング像から、約 $132 \mathrm{~nm}$ の棒状の部分とその両端にノブ様 の部分を持つ全長 $160 \mathrm{~nm}$ の分子形態が明らかにされた(9)。この 構造はcDNAの塩基配列から予想される構造(9)、さらに免疫電 子影微鏡による研究䊅果(24)と一致した。以上のデータによ り、VIII型コラーゲンはデスメ膜で観察された六角形の格子構 造を棈成していることが確認された(24)。しかし小量ながらVIII 型コラーゲンは眼の他の場所、たとえばブルック膜、視神経の 節板、シュレム管壁、脈絡膜実質にも存在し(25)、また軟骨 膜、骨膜、䯣膜、強膜などの他の細胞外マトリックスにも局在 している(26、27)。さらにKittelbergerと共同研究者(28)は、VIII 型コラーゲンが毛根鞘の結合組織に存在することを報告してい る。この毛根鞘はミクロフィブリルであるオキシタラン線維に 富み(29)、数人の研究者はVIII型コラーゲンが弾性線維のミクロ フィブリルを形成していることを観察している(27、30)。しか しこのような現象はすべての組織に認められるわけではなく、 弾性線維の豊富な項勒帯ではVIII型コラーゲンは検出されてい ない(27)。VIII型コラーゲンはまた血管内皮下層(内膜)や新生毛 細血管の成分でもある(31、32)。最後に星状細胞腫、ガン化し たケラチノサイト、歯肉上皮細胞が培養系でかなりの量のVIII 型コラーゲンを産生分泌することを付け加えておく(33-35)。図 4 に皮虐(A、B)、小血管(C、D)、さらに骨膜や軟骨膜(E、F)の ような特殊なマトリックスにおけるVIII型コラーゲンの分布を 示した。

発生の過程では、VIII型コラーゲンは妊娠中期のトリおよ びマウス胚で合成、発現される。発生11日のマウス胚で、初め て頭部に間葉組織が出現する。12日目には抗VIII型コラーゲン 抗体で小血管が染色され、より大きな血管の内皮下層はそれ以 降のステージで免疫染色陽性となる(19)。血管系におけるVIII型 コラーゲンの発現は、心臟の発生分化にも関連しており、心臓 ではある特定の場所に、しかもある一時期のみ発現されるよう に調節されている。VIII型コラーゲンは最初、免疫細胞化学的 な手法により、12日肧の心葴の筋芽細胞に認められた。その後 17日まで染色は陽性であったが、17日以降、徐々に染色性は减 弱し、出生後の動物では全く検出されなかった。VIII型コラー ゲンはまた、マウスの13日から17日脹の心葴内隆起にも存在す る(19)。これは心茂弁の前駆体である。しかしこのタンパク質 の分布は急速に変化する。最初は心筋層と、心筋層の基底膜と して知られている心臓のゼリー間の移行部に認められる。15日 になると、VIII型コラーゲンは発生段階の心葴弁の心内膜下層 に存在する。ところが、以後のステージ(17日)では、心缄弁の 実質にのみ存在するようになった。成体においては、VIII型コ ラーゲンは心荿弁や心筋層には存在せず、大血管の内膜下層に 存在する。Kittelbergerと共同研究者も同様な報告をしている (28)。 
several investigators have observed that type VIII collagen is often coincident with microfibrils in elastic fibers $(27,30)$. This association is not characteristic of all tissues, however, as type VIII collagen has not been detected in nuchal ligament(27), a structure containing abundant elastic fibers. Type VIII collagen is also a component of the subendothelium(tunica intima) of blood vessels $(19,28)$ and of newly-formed capillaries $(31$, 32). Finally, astrocytoma cells, transformed keratinocytes, and gingival epithelial cells secrete significant amounts of type VIII collagen in vitro $(33,34,35)$. Fig. 4 illustrates the distribution
心臟の発生段階におけるVIII型コラーゲンのユニークな発 現パターンは、このタンパク質が筋芽細胞の分化と関係してい ることを示している。発生分化の各ステージに相関して、特定 の細胞外マトリックス成分が心筋層に出現する現象が知られて いる(36)。たとえば、I型コラーゲンの分泌は、心葴内隆起の上 皮一間葉系の形質転換と梁いつながりがある。線維型のI型コ ラーゲンは、この形質転換のマーカーであり、心臓内の内皮細 胞が心臓のゼリーへ遊走する際の足場を提供している(37)。筋 芽細胞の分化には、VIII型コラーゲンを含む数種の細胞外間質 分子が必要であると思われる。それらの分子は、細胞の遊走、
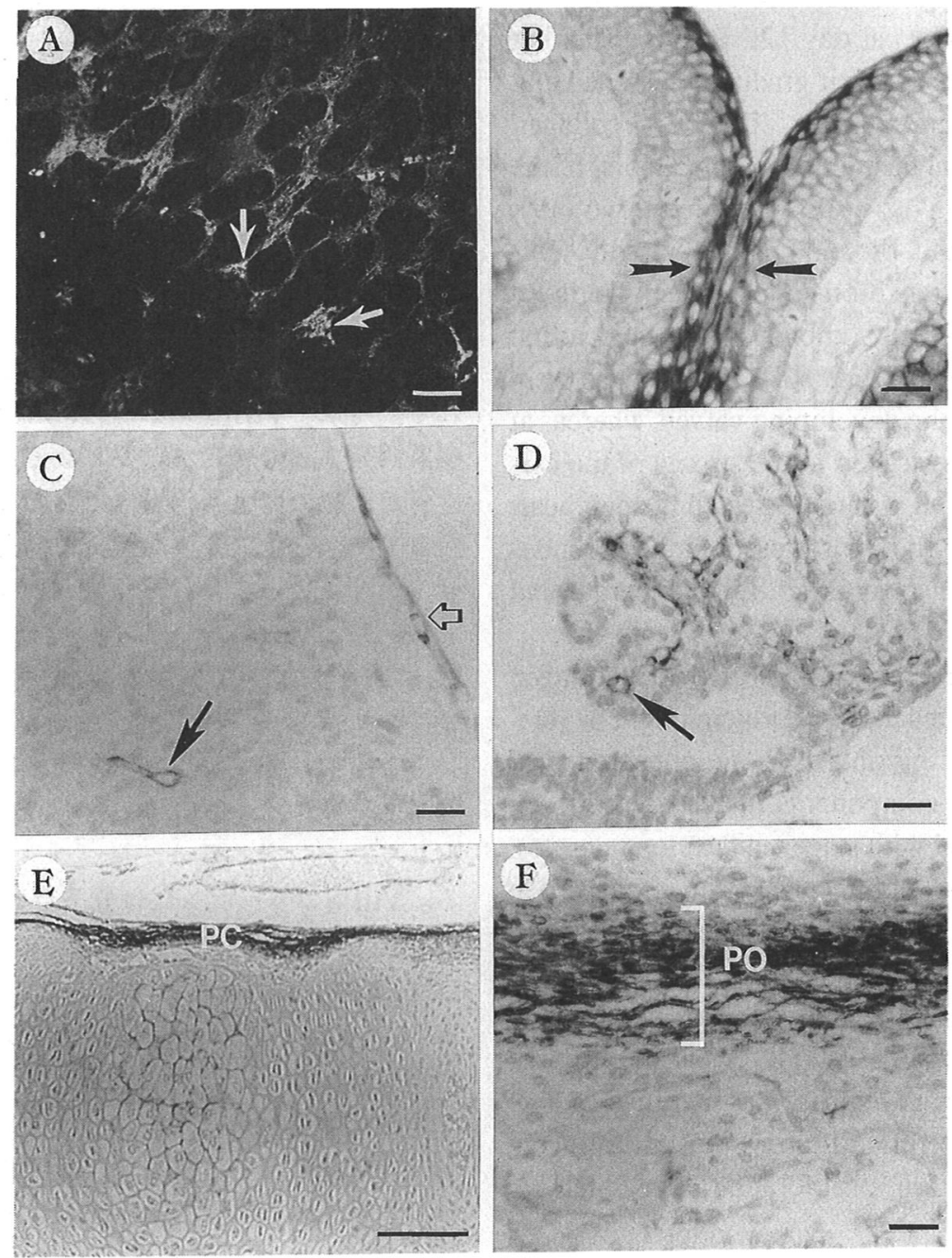

Fig. 4. Immunolocalization of type VIII collagen in tissues. Paraffin sections of mouse tissues were incubated with a polyclonal affinity-purified anti-type VIII collagen IgG(19). Immunolocalization was performed by indirect immunofluorescence(A) or with an avidinbiotin-peroxidase technique(B-F) followed by detection with diaminobenzidine. A light counterstaining with toluidine blue was used in B - F to identify surrounding structures. This counterstain appears in the photomicrographs as a light gray, in contrast to the black color of the immunopositive reaction product. A) Transverse section of hair follicles. Immunoreactivity is associated with the connective tissue sheath that surrounds each hair follicle(arrows); B) Neonatal mouse skin(area of fused eyelids). Type VIII collagen is detected in the terminally differentiated layer of keratinocytes, particularly in regions of immediate contact(arrows); C) Neonatal mouse brain. Open arrow points to the pia mater, which shows discrete reactivity with anti-type VIII collagen IgG. In the gray matter, small vessels can be easily identified(closed arrow); D) Choroid plexus. Arrow indicates a capillary consisting of one cell positive for type VIII collagen. Immunoreactivity with anti-type VIII collagen IgG can also be identified in several other vessels, particularly those under the cuboidal epithelium; E) Cartilage. The perichondrium(PC) displays strong immunoreactivity; F) Bone. The periosteum(PO) shows a strong fibrillar pattern corresponding to type VIII collagen. Bar: $100 \mu \mathrm{m}$. 
of type VIII collagen in skin (A, B), small vessels (C, D), and specialized matrices such as periosteum and perichondrium $(E$, F).

During development, type VIII collagen is expressed in mid-gestation chicken and mouse embryos. At day 11 of mouse development, it was first observed in the head mesenchyme. Small vessels stained positively for type VIII collagen by day 12 , and the subendothelium of larger vessels was immunolabeled at later stages(19). The expression of type VIII collagen in the vascular system extends to the developing heart, in which the distribution is spatially and temporally regulated. Initially, type VIII collagen was detected by immunocytochemistry in cardiac myoblasts at day 12 . Positive staining was present until day 17 , after which it gradually lessened and was undetectable in postpartum animals. Type VIII collagen was also present in endocardial cushions, the precursors of the cardiac valves(day 13 through 17 in the mouse embryo)(19); however, the distribution of this protein changed rapidly. Initially, it was observed in the transition zone between the myocardium and the cardiac jelly (also known as the myocardial basement membrane). At day 15, type VIII collagen was present in the subendocardium of the developing valves, whereas at later stages(17 days), it was restricted to the stroma of the cardiac valves. Type VIII collagen was not detected in adult heart valves or myocardium, although it was present in the subendothelium of large vessels, as also reported by Kittelberger and coworkers(28).

The unique pattern of expression of type VIII collagen in the developing heart indicates that this protein might be relevant to the differentiation of myoblasts. The appearance of specific extracellular matrix components in the myocardium has previously been correlated with stages in development(36). For example, secretion of type I collagen has been implicated in the epithelial-mesenchymal transformation observed in cardiac cushions. Fibrillar type I collagen, a marker for this transformation, provides support for the migration of endocardial endothelial cells into the cardiac jelly(37). We have proposed that differentiation of myoblasts requires the presence of several extracellular molecules, including type VIII collagen, which could facilitate migration, proliferation, or cellular recognition and sorting(19).

The precise spatial and temporal regulation of type VIII collagen in the developing heart has elicited further speculation that the protein might function in tissue remodeling and cell differentiation. Transient expression during embryogenesis has been described for several extracellular proteins that include collagens. For example, types II and IX collagen are found in the embryonic but not in the adult chicken cornea(38, 39 ), and type IV collagen might contribute to the provisional matrix of migrating neural crest cells(40). Such transiently expressed structural molecules are thought to provide bio-
増殖、細胞間の認識や識別を助けるものと考えられている (19)。

心臟の発生分化過程において、VIII型コラーゲンの発現部 位と発現時期が正確に制御されていることから、このタンパク 質は、組織の再棈築や細胞分化に何らかの機能を果たしている と予想している。コラーゲンを始めとして、数種の細胞間質夕 ンパクが胚形成期に一過性に発現されることが知られている。 たとえば、II型、IX型コラーゲンは胎児性の角膜には存在する が、成長したトリの角膜には存在しない(38、39)。また、神経 冠細胞が遊走する時には、IV型コラーゲンによる一時的な仮の マトリックスが形成される(40)。このように一過性に発現され ろ棈造分子は、細胞の誘導や分化を促進する生化学的な情報を 提供していると考えられる。これらの分子は、細胞表面の受容 体と直接結合したり、增殖因子と䊅合して細胞と增殖因子の反 応を抑制したり、他のマトリックス分子と会合してマトリック スのトポロジーを調節することなどによって、細胞の挙動を調 節しているのであろう。

現時点では、VIII型コラーゲンの心裁形成における役割は 推測の域を出ないが、本コラーゲンの発現が調節されているこ とから、心臓の発生分化を決定する重要な因子であると考えら れる。将来、VIII型コラーゲンのジーンターゲティングや突然 变異誘発などの研究が必要となるであろう。この細胞外タンパ ク質が、肧の発生分化過程でどのような役割を果たすかを研究 する上で、分子の合成を完全に抑えたり不完全な分子を合成さ せることによって、貴重な情報が得られるものと思われる。

\section{E. VIII型コラーゲンの生物学的機能: 血管形成における} 役割?

VIII型コラーゲンは、多種多様な培養内皮細胞の分泌成分 として発見された(17、41)。例えば、ウシ大動脈内皮細胞のVIII 型コラーゲン合成量は、全コラーゲン合成量の $25 \%$ 占めてい る。VIII型コラーゲンには分子量の異なる3種のイソ型が報告さ れており、それぞれ分子量177,000、125,000、100,000で、 $\mathrm{EC} 1 、 \mathrm{EC} 2 、 \mathrm{EC} 3$ と呼ばれている。ペプチドマッブから、EC2 と EC3は、EC1に由来するものであると考えられている(42)。EC1 とEC2をペブシンで消化すると、分子量50,000のこれ以上分解 をうけない安定な断片が得られ、この断片は、アフィニティク ロマトグラフィーで精製した抗VIII型コラーゲンIgGと反応する (43)。免疫細胞化学的な手法により、内皮細胞の培養系から、 VIII型コラーゲンは内皮のマトリックスに存在することがわ かった。この知見は、生体内ではこのコラーゲンが、ある種の 血管の内皮下層に存在することとよく対応している(19、27)。 さらに、培羑内皮細胞がひも、ないしは管状の構造を形成する 時、VIII型コラーゲンの合成が増加することが知られている (31、43)。この情報が生体内での血管形成とどのように結びつ くのかは明らかではないが、VIII型コラーゲンが、脳の新生血 管の構築に関係しているという報告がなされている(32)。

生体内においては、内皮細胞がVIII型コラーゲンを産生し ているという確たる証拠がある。そのほとんどのデータは、ア 
chemical information that facilitates cellular induction and differentiation. These molecules might regulate cell behavior by binding directly to cell surface receptors, by sequestering growth factors, and/or by regulating matrix topography through an association with other matrix molecules.

Although any role that type VIII collagen might play in cardiogenesis is speculative at this point, regulation of its expression appears to be an important factor in directing the development of the heart. Future experiments should include gene targeting and mutagenesis of the type VIII collagen gene. The ablation or genesis of a defective molecule would provide valuable information concerning the function of this extracellular protein during embryonic development.

\section{E. Cell Biology of Type VIII Collagen: A Role in Angio- genesis?}

Type VIII collagen has been found as a secreted component of a large variety of endothelial cells in culture $(17,41)$. In bovine aortic endothelial cells, for example, it accounts for $25 \%$ of total collagen synthesis. Three isoforms of different molecular size have been reported: EC1, EC2, and EC3, of approximate Mr 177,000, 125,000, and 100,000, respectively. From peptide maps, it was suggested that EC2 and EC3 were related to $\mathrm{EC1}$ (42). Digestion of EC1 and EC2 with pepsin generated stable fragments of $\mathrm{Mr} 50,000$ that were recognized by affinitypurified anti-type VIII collagen IgG(43).

Immunocytochemical studies of cultured endothelial cells revealed type VIII collagen in the endothelial matrix, a finding compatible with the location of this collagen in the subendothelium of certain vessels in vivo $(19,27)$. In addition, type VIII collagen was increased when endothelial cells formed cord and tube-like structures in vitro $(31,43)$. Whether this information is relevant to angiogenesis in vivo is unclear, although there are indications that type VIII collagen might participate in the organization of new blood vessels in the brain(32).

In vivo, there is good evidence that endothelial cells produce type VIII collagen. Most of these data have been derived from immunolocalization studies performed with affinity-purified polyclonal or monoclonal antibodies. Several investigators have observed type VIII collagen in the subendothelium of medium and large vessels $(13,27,28)$. Type VIII collagen is also present in capillaries of embryonic mice(31) and in microvessels associated with a number of human brain tumors(32). During development, positive staining for type VIII collagen is seen in organs which undergo vascularization primarily by angiogenesis, such as brain (see Fig. 4, C and D). Although these data indicate a potential role in the genesis of new blood vessels, it is difficult to delineate a specific function for type VIII collagen in the morphogenetic process of neovascularization. Early studies showed that type VIII collagen was
フィニティクロマトグラフィーで精製したポリクローン抗体、 あるいはモノクローン抗体を用いた免疫組織染色の䊅果得られ たものである。数人の研究者は、VIII型コラーゲンが中程度の 血管ないしは、大血管の内皮下層に存在することを観察してい る(13、27、28)。VIII型コラーゲンはまた胎生マウスの毛細血管 (31)、ヒト脳腫瘍に結合している微小血管にも存在する(32)。発 生分化の過程では、血管の新生により、主として血管形成の盛 んな脳などの䁍器で、VIII型コラーゲンの染色が淂性となる (図4、CとDを参照)。これらのデータはVIII型コラーゲンが新生 血管の形成を促進する役割を果たしていることを示している。 にもかかわらず、血管が新生される際に、血管の形態形成過程 において、VIII型コラーゲンがどのような特別な機能を果たす のかを正確に記述するのは難しい。初期の研究から、VIII型コ ラーゲンは增殖能や遊走能の高い細胞と特異的に会合している ことが知られている(41、44)。面白いことに、この点に関連し て、VIII型コラーゲンは星状細胞腫(神経膠腫)を始めとする多数 の悪性腫瘍細胞系の培養液に存在することが知られている (17)。これらの細胞は、正常組織においては䑈血管と密着して 存在している細胞である。培養系におけるVIII型コラーゲンの 合成は、生体内におけるその分布と非常によく相関している。 従って、VIII型コラーゲンの発現が生体内外で一致しているこ とは、本コラーゲンの調節や機能に関係するより核心的な問題 をすでに確立された実験系を用いて究明していく上で、非常に 都合がよいと思われる。

F. おわりに

VIII型コラーゲンは、デスメ膜に見られる六角系格子䊦造 の構成成分としての機能を持っていることが明らかであるにも かかわらず、内皮細胞の合成産物としての役割や、血管系、軟 骨膜、骨膜、硬膜、眼組織、そして軟骨などの特定の䊅合組織 における機能は明らかではない(24、26、27)。またVIII型コラー ゲンとX型コラーゲンのアミノ酸および塩基配列の相同性が、 類似した機能を反映したものかどうかもはっきりしていない。 X型コラーゲンの組織分布は、主として軟骨成長板の肥大(軟骨 細胞)層に限られており(14)、明らかにVIII型コラーゲンの分布 とは一致しない。

我々は最近、角膜の発生初期のステージ、胎生14日から15 日の間、一次性角膜実質にVIII型コラーゲンが出現し、胎生 17 日ではこの組織から消失してしまうことを明らかにした(L. Chun とH. Sage、論文作成中)。一次性角膜実質も肥大軟骨と同 様に、組織の再棈築が行われている間、組織を支えている一時 的なマトリックスである。VIII型コラーゲンとX型コラーゲン は、両者のユニークな棈造上の特徽から、組織再構成において

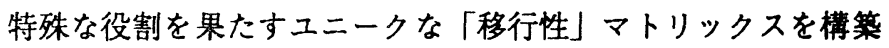
することができるのであろう。線維型コラーゲンに比較して、 X型、VIII型コラーゲンは熱に安定で、それ故、代謝活性の高い 環境に適応しやすいのかもしれない。三本鎖へリックス領域は 何ケ所もへリックス構造が中断されているが、この構造は組織 のタンパク質分解酵素によって迅速に分解される自由度の高い 
preferentially associated with highly proliferative and migratory cells $(41,44)$. In this regard, it is interesting that type VIII collagen was found in the culture media of a significant number of malignant lines that included astrocytoma(glioma) cells, which are closely associated in normal tissue with the cerebral vasculature(17). The synthesis of type VIII collagen in vitro correlates reasonably well with its distribution in vivo. This coincidence of expression is favorable for the pursuit of more specific questions concerning the regulation and function of type VIII collagen in well-defined systems.

\section{F. Concluding Remarks}

Although type VIII collagen appears to function as a component of the hexagonal lattice observed in Descemet's membrane, its role as a product of endothelial cells(31), in vasculature $(19,28)$, or in specialized connective tissues such as perichondrium, periosteum, dura mater, ocular tissues, and cartilage $(24,26,27)$ is less apparent. It is also uncertain whether the sequence homology between types VIII and X collagen reflects a functional homology. The tissue distribution of type $\mathrm{X}$ collagen, which is restricted primarily to the hypertrophic zone of growth plate cartilage(14), clearly does not coincide with that of type VIII collagen.

We have recently shown that type VIII collagen appears in the primary corneal stroma during the early stages of corneal development(embryonic day 14 and 15) but disappears from this tissue by embryonic day 17(Fig.5)(L. Chun and H. Sage, manuscript in preparation). Similar to hypertrophic cartilage, the primary stroma is a temporary matrix that supports the tissue during remodeling. As a consequence of their unique structural features, types VIII and X collagens could assemble into unique "transitional" matrices which play a specialized role in remodeling tissues. Compared to the fibrillar collagens, both type $\mathrm{X}$ and type VIII collagens are thermally more stable and may therefore be better adapted to metabolically active environments. A triple-helical domain containing multiple interruptions is also suitable for a flexible structure that can be rapidly degraded by tissue proteases. Type VIII collagen is associated with angiogenesis in vitro(43) and with capillary formation in vivo(31); it is also expressed at epithelial-mesenchymal interfaces during cardiac morphogenesis(19). In each instance, the unique structure of type VIII collagen might be required for the transitional matrices that are established during the morphogenesis of specific tissues.

The protein structure of type VIII collagen remains an unresolved question. Although two genes have been characterized, there is good evidence for the existence of a protein larger than that predicted from the cDNAs. The transcriptional products of both type VIII collagen genes, $\alpha 1$ (VIII) and $\alpha 2$ (VIII), encode polypeptide chains of approximate $\mathrm{Mr} 60,000$. However, the existence of a larger molecule has been suggested by

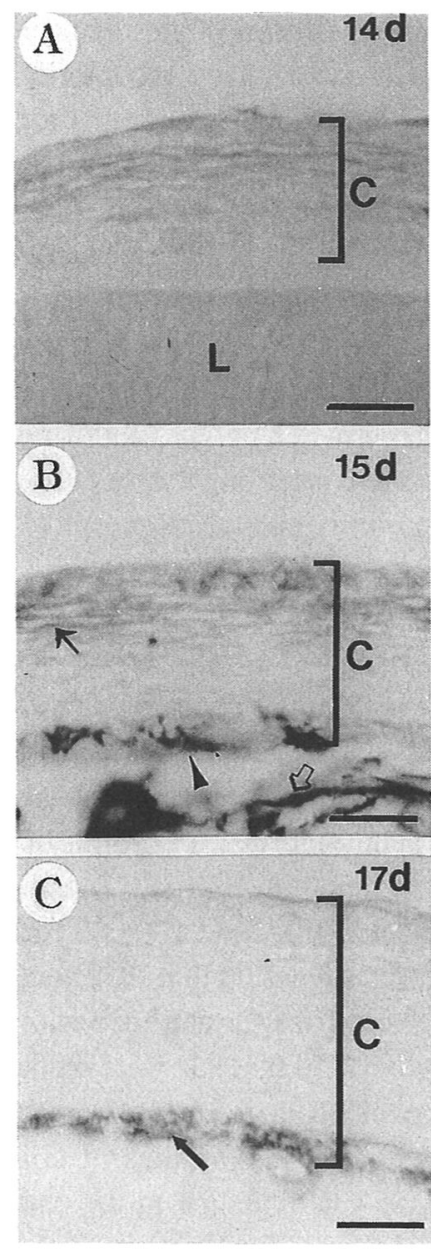

Fig. 5. Distribution of type VIII collagen in developing mouse cornea. Paraffin sections of developing mouse cornea at day $14(\mathrm{~A}), 15(\mathrm{~B})$, and $17(\mathrm{C})$ were incubated with monoclonal anti-type VIII collagen IgG. Immunoreactivity was visualized by an avidinbiotin-peroxidase treatment followed by diaminobenzidine. Reactivity with anti-type VIII collagen IgG was identified in the stroma of the cornea(labeled C) at day 14(A). At day 15(B), fibrillar immunoreactivity was evident in the stroma(arrow). The newly-organized Descemet's membrane exhibited strong but discontinuous reactivity (arrowhead). Small vessels are also stained with anti-type VIII collagen $\mathrm{IgG}$ (open arrow). On day $17(\mathrm{C})$, the stroma appears negative and the reactivity of the organized Descemet's membrane is now apparent (arrow). L, Lens. Bar: $100 \mu \mathrm{m}$.

構造と適合している。VIII型コラーゲンは、培盖系における血 管形成(43)、生体内における毛細血管の形成(31)に関与してい る。また心臓の形態形成が行われている間、上皮一間葉系の境 界に発現される(19)。それぞれの場合において、特定の組織の 形態形成期間に作られる移行性のマトリックスに、このVIII型 コラーゲンのユニークな構造が必要とされているのかもしれな w。

VIII型コラーゲンのタンパク質構造は未解決の問題として 残されている。2つの遺伝子が解明されたが、cDNAから予想さ れるタンパク質より高分子量のタンパク質が存在する確かな証 拠がある。VIII型コラーゲン遺伝子、 $\alpha 1(\mathrm{VIII})$ と $\alpha 2(\mathrm{VIII})$ )転写 
studies of protein purified from cultured cells and from tissues. Metabolically labeled type VIII collagen from several types of endothelial cells, an astrocytoma cell line, transformed murine keratinocytes, and human gingival epithelial cells has consistently been purified as two and occasionally three chains of approximate Mr 180,000,125,000, and/or 100,000(33-35, 42, 45). Although studies in vitro are subject to artefacts, cultured cells have been used successfully to study the synthesis and secretion of molecules. For example, certain forms of procollagen that can be purified readily from culture medium are difficult to isolate from tissues in which rapid proteolytic processing occurs. The large forms of type VIII collagen produced in vitro could be an example of an immature, intermediate, or extremely labile tissue form of the protein. After purification from culture medium, the larger forms are unusually susceptible to cleavage by pepsin, as well as by several neutral serine proteases, under conditions in which other collagens are relatively resistant $(42,45)$. This lability is indicative of a partially unfolded or interrupted triple helix and could explain the difficulties encountered in purifying an intact form of type VIII collagen from tissues. However, tissue extracts from developing mouse hearts contained high molecular weight forms that could be identified by specific affinity-purified anti-type VIII collagen antibodies(19). The higher molecular weight forms that have been described for type VIII collagen could be explained by the existence of a third gene encoding for a large polypeptide chain, as shown for type VI collagen(46). Alternatively, type VIII collagen might associate with proteoglycans or glycosaminoglycans in the extracellular space, an interaction predicted from the basic nature of the NC2 domain of $\alpha 1$ (VIII) (9) and from its apparent sensitivity to hyaluronidase(19).

In summary, we have presented an overview of the research that has been conducted on the type VIII collagen genes and protein. It was our goal to discuss the available information in a context that would outline some of the basic questions that remain unanswered. Future directions include the identification of regulatory elements in type VIII collagen genes that contribute to the unusual patterns of expression observed for the corresponding protein. The recent cloning of the $\alpha 1$ and $\alpha 2$ (VIII) genes, and the use of cultured cells that express type VIII collagen, will greatly accelerate this process. Secondly, it will be important to characterize the higher molecular weight forms of the type VIII collagen protein to understand its role and interactions with other components of the extracellular matrix. The cloning of murine type VIII collagen genes will facilitate studies on the role of this protein in development through the ablation of the gene by homologous recombination or by overexpression of the gene product in transgenic animals. It is our belief that the study of type VIII collagen will provide novel insight into the role of specific extracellular matrix proteins in cell regulation.
産物は、分子量約 60,000 のポリペプチド鎖をコードしている。 しかし、培養細胞や組織から精製されたタンパクの研究䊅果 は、より高分子量の分子が存在する可能性を示している。数種 の内皮細胞、星状細胞腫系、ガン化したマウスケラチノサイ 卜、ヒト歯肉上皮細胞などの培養系で、VIII型コラーゲンを代 謝的に標識すると、常時2種の、時には3種のポリベプチド鎖が 精製され、その分子量は約 $180,000 、 125,000$ と100,000である *3(33-35、42、45)。培養系の研究は人為的な実験誤差を生じや すいが、培養細胞は分子の合成、分泌の研究に成功裏に利用さ れてきた。たとえば、ある形態のブロコラーゲンは、培盖液か ら簡単に精製できるが、組織から単離するのは困難である。組 織では急速なタンバク分解による修飾がおこるからである。培 養系で産生される高分子量のVIII型コラーゲンは、未熟な形ゃ 中間体であるかもしれないし、極端に分解されやすい組織形の タンバク質である可能性もある。培養液から精製した後、高分 子形のVIII型コラーゲンは、他のコラーゲンが比較的タンパク 質分解に抵抗性を示す条件下でもペプシンや数種の中性セリン プロテアーゼによる分解を受けやすい(42、45)。この不安定な 性質は、三本鎖へリックスが一部巻き戻っていたり、中断して いることを示している。また組織からそのままの形のVIII型コ ラーゲンを精製することが、いかに困榷であるかを説明してい る。しかし、分化発生過程のマウスの心䑏から得られる組織抽 出液には、アフィニティクロマトグラフィーで精製した特異的 な抗VIII型コラーゲン抗体と反応する高分子量の形態が含まれ ていた(19)。上述のVIII型コラーゲンの高分子形は、VI型コラー ゲンのように、より大きなポリペブチド鎖をコードする3番目の 遺伝子が存在することで、説明できるかもしれない(46)。ある いは、VIII型コラーゲンは細胞外ではブロテオグリカンやグリ コサミノグリカンと会合して存在するのかもしれない。 $\alpha 1(\mathrm{VIII}) の \mathrm{NC} 2$ 領域が塩基性であること(9)や、ヒアルロニダー ゼに対して明らかに感受性であること(19)からそれらの会合の 存在が予想される。

要約すると、我々はVIII型コラーゲンの遺伝子とタンバク 質について行われてきた研究を概説した。我々の最終目標は、 利用できる情報を論議して、未解決のまま残されたいくつかの 基本的な問題を明らかにすることであった。これからの研究 は、VIII型コラーゲン遺伝子の調節エレメントを見つけ、この タンパク質で認められている珍しい発現パターンを解明するこ とを目ざしている。最近クローニングされた $11 、 \alpha 2(\mathrm{VIII})$ 遺伝 子とVIII型コラーゲンを発現する培養細胞系を利用することに よって、問題解決時期が早められると考えている。次に、VIII 型コラーゲンタンバク質の高分子量形の性質を解明して、その 機能と他の細胞外マトリックス成分との相互作用を理解するこ とが重要であると考えている。マウスVIII型コラーゲン速伝子 のクローニングによって、発生分化におけるこのタンバク質の

\footnotetext{
-3星状細胞腫の培養液にはEC2(分子量 125,000 )とEC3(分子量 $100,000) 、$ 、シ大動脈内皮細胞の培養液にはEC1(分子量 180,000$)$ とEC2、ウシ大静脈内皮細胞の培養液にはEC1、EC2、EC3のポ リペプチド鎖が存在する。
} 


\section{Acknowledgements}

The authors thank Dr. Paula Hasselaar and Timothy Lane for their critical comments. Work from the authors' laboratory was supported by National Institutes of Health grant HL18645.
役割を研究することが容易になった。これらの研究には、トラ ンスジェニックマウスにおいて相同遺伝子を除去したり、遗伝 子産物を過㮃に発現させる実験も含まれる。VIII型コラーゲン の研究は、特定の細胞外マトリックスタンパク質が、細胞の制 御にどのような役割を果たしているかを考察する上で、貴重な 資料を提供してくれるものと信してている。

\section{東京医科歯科大学・難治疾患研究所 \\ 山口 典子 訳}

\section{References}

1. Ninomiya, Y., Showalter, A.M., and Olsen, B.R. (1984) in The Role of Extracellular Matrix in Development (Trelstad, R.L., ed.) pp 255-276. Alan R. Liss, New York

2. Albelda, S.M., and Buck, C.A. (1990) FASEB J. 4, 2868-2880

3. Bornstein, P., and Sage, H. (1989) Prog. Nuc. Acids Res. Mol. Biol. 37, 66-105

4. Jacenko, O., Olsen, B.R., and LuValle, P. (1991) Crit. Rev. Gene Exp. 1, 327-353

5. Yamaguchi, N., Mayne, R., and Ninomiya, Y. (1991) J. Biol. Chem. 266, 4508-4513

6. Muragaki, Y., Mattei, M-G., Yamaguchi, N., Olsen, B.R., and Ninomiya, Y. (1991) Eur. J. Biochem. 197, 615-622

7. Muragaki, Y., Jacenko, O., Apte., S., Mattei, M.-G., Ninomiya, Y., and Olsen, B.R. (1991) J. Biol. Chem. 266, 7721-7727

8. Kapoor, R., Bornstein, P., and Sage, H. (1986) Biochemistry 25, 3930-3937

9. Yamaguchi, N., Benya, P.D. , van der Rest, M., and Ninomiya, Y. (1989) J. Biol. Chem. 264, 16022-16029

10. Mann, K., Jander, R., Korsching, E., Kühn, K., and Rauterberg, J. (1990) FEBS Lett. 273, 168-172

11. Ninomiya, Y., Castagnola, P., Gerecke, D., Gordon, M.K., Jacenko, O., LuValle, P., McCarthy, M., Muragaki, Y., Nishimura, I., Oh, S., Rosenblum, N., Sato, N., Sugrue, S., Taylor, R., Vasios, G., Yamaguchi, N., and Olsen, B.R. (1990) in Extracellular Matrix Genes (Sandell, L.J., and Boyd, C.D., eds.) pp. 79-114. Academic Press, New York

12. Bornstein, P., and Traub, W. (1979) in The Proteins. (Neurath, H., and Hill, R. L., eds.) Vol. 4, pp. 412-605 Academic Press, New York

13. Jander, R., Korsching, E., and Rauterberg, J. (1990) Eur. J. Biochem. 189, 601-607

14. Schmid, T.M., Mayne, R., Jeffrey, J.J., and Linsenmayer, T.F. (1986) J. Cell Biol. 109, 939-945

15. Benya, P. (1980) Renal Physiol. 3, 30-35

16. Benya, P.D., and Padilla, S.R. (1986) J. Biol. Chem. 261, 4160-4169

17. Sage, H., and Bornstein, P. (1987) in Biology of the Extracellular Matrix: Structure and Function of Collagen Types (Mayne, R. and Burgeson, R., eds.) pp. 173-194. Academic Press, Orlando, FL.

18. Labermeier, U., Demlow, T.A., and Kenney, M.C. (1983) Exp. Eye Res. 37, 225-237

19. Iruela-Arispe, M.L., and Sage, E.H. (1991) Dev. Biol. 144, 107-118

20. Labermeier, U., and Kenney, M. C. (1983) Biochem. Biophys. Res. Comm. 116, 619-625

21. Kapoor, R., Bornstein, P., and Sage, H. (1985). in Basement Membranes (Shibata, S., ed.) pp. 105-118 Elsevier Science Publishers, Amsterdam

22. Davis, P.F., Ryan, P.A., Kittelberger, R., and Greenhill, N.S. (1990) Biochem. Biophys. Res. Commun. 171, 260-265

23. Sawada, H., Konomi, H., and Nagai, Y. (1984) Eur. J. Cell Biol. 35, 226-234

24. Sawada, H., Konomi, H., and Hirosawa, K. (1990) J. Cell Biol. 110, 219-227

25. Tamura, Y., Konomi, H., Sawada, H., Takashima, S., and Nakajima, A. (1991) Invest. Ophthalmol. Vis. Sci. 32, 2636-2644

26. Kapoor, R., Sakai, L. Y., Funk, S., Roux, E., Bornstein, P., and Sage, E.H. (1988) J. Cell Biol. 107, 721-730

27. Kittelberger, R., Davis, P.F., Flynn, D.W., and Greenhill, N.S. (1990) Connect. Tiss. Res. 24, 303-318

28. Kittelberger, R., Davis, P.F., and Greenhill, N.S. (1989) Biochem. Biophys. Res. Comm. 159, 414-419

29. Cotta-Pereira, G., Guerra-Rodrigo, F., and Sampaio, S.B. (1977) J.Invest. Dermatol. 66, 143-151

30. Sakai, L.Y., Roux, E.R., Bornstein, P., Sage, H., and Ciment, G.(1987) J. Cell Biol. 105, 214a

31. Sage, H., and Iruela-Arispe, M. L. (1990) Ann. N.Y. Acad. Sci. 580, 17-31

32. Paulus, W., Sage, E.H., Liszka, U., Iruela-Arispe, M.L., and Jellinger, K. (1991) Brit. J. Cancer 63, 367-371

33. Alitalo, K., Bomstein, P., Vaheri, A., and Sage, H. (1983) J. Biol. Chem. 258, 2653-2661

34. Tokimitsu, I., Ohyama, K., Tajima, S., and Nishikawa, T. (1991) J. Invest. Dermatol. 96, 267-272

35. Salonen, J., Oda, D., Funk, S., and Sage, H. (1991) J. Periodont. Res. 26, 355-360

36. Borg, T.K., Rubin, K., Lundgreun, E., Borg, K., and Obrink, B. (1984)Dev. Biol. 104, 86-96

37. Mjaatvedt, C.H., and Markwald, R.R. (1989) Dev. Biol. 136, 118-128

38. von der Mark, K., von der Mark, H., Timpl, R., and Trelstad, R.L. (1977) Dev. Biol. 59, 75-85

39. Fitch, J.M., Mentzer, A., Mayne, R., and Linsenmayer, T.F. (1988) Dev. Biol. 128, 396-405

40. Perris, R., Krotoski, D., and Bronner-Fraser, M. (1991) Development, in press.

41. Sage, E.H. (1986) in Contemporary Issues in Haemostasis and Thrombosis: Vascular Endothelium in Haemostasis and Thrombosis (Gimbrone, M., ed) Vol. 2, pp. 198-208. Churchill Livingstone, Edinburgh

42. Sage, H., Pritzl, P., and Bornstein, P. (1980) Biochemistry 19, 5747-5755

43. Iruela-Arispe, M.L., Diglio, C.A., and Sage, E.H. (1991) Arterioscler. Thromb. 11, 805-815

44. Sage, H., Balian, G., Vogel, A.M., and Bornstein, P. (1984) Lab. Invest. 50, 219-231

45. Sage, H., Trüleb, B., and Bornstein, P. (1983) J. Biol. Chem. 258, 13391-13401

46. Trüeb, B., and Winterhalter, K.H. (1986) EMBO J. 5, 2815-2819 